\title{
Planning and Designing The Creative Industry and Start-Up Co- WORKING SPACE IN SURAKaRTa
}

\section{PerencanaAn dan Perancangan Kantor Sewa Kolaboratif Industri KREATIF DAN BISNIS RINTISAN DI SURAKARTA}

\author{
Nabila Hanif Farah ${ }^{1 *}$, Ana Hardiana ${ }^{2}$, M. Muqoffa ${ }^{3}$ \\ Program Studi Arsitektur, Fakultas Teknik Universitas Sebelas Maret Surakarta ${ }^{1 *}$ \\ nabilahaniffarah@gmail.com \\ Program Studi Arsitektur, Fakultas Teknik Universitas Sebelas Maret Surakarta ${ }^{2}$ \\ Program Studi Arsitektur, Fakultas Teknik Universitas Sebelas Maret Surakarta ${ }^{3}$
}

\begin{abstract}
Surakarta City is designated as National Activity Center (PKN) on the National Spatial Plan $(R T R W N)$ in the development of the creative economy sector. The determination is reinforced by Bekraf Developer Day 2017 and the Economic Census of the Central Bureau of Statistics which shows that Surakarta has more than 1250 creative workers. $65.75 \%$ of them have no place to work, so they do their work at home and or cafe. Problems that arise are how to design facilities and comfortable workspace so that the creative workers can make presentations and discussions with colleagues without being disturbed by the noise of other cafe visitors, or by family activities at home. In order to connect between start-up and creative workers, and to create a comfortable workspace to improve productivity and creativity of its users, is required collaborative working space (office) for creative industry workers and start-up in Surakarta City. The design of collaborative working space is done by collecting primary and secondary data through interviews, observation, precedent study, book literature study, local regulations, articles, and news. The data sets are then analyzed and synthesized to produce the concept of the space character criteria and the concept of the shape and appearance of the space which is then transformed into a collaborative working space design that supports the productivity and creativity of its users in Surakarta.
\end{abstract}

Keywords: Collaborative Workspace, Productive, Creative, Surakarta.

\section{PENDAHULUAN}

Kantor Sewa Kolaboratif Industri Kreatif dan Bisnis Rintisan di Surakarta adalah co-working space (collaborative working space) ruang kantor bersama yang bisa disewa oleh pekerja industri kreatif dan atau bisnis rintisan (start-up company) secara harian, mingguan, bulanan, atau tahunan (Husada, 2015) bagi masyarakat Surakarta dan pengunjung Kota Surakarta.

Kota Surakarta berfungsi sebagai Kawasan Andalan dalam konstelasi pengembangan wilayah regional Subosukawonosraten (Surakarta, Boyolali, Sukoharjo, Karanganyar,
Wonogiri, Sragen dan Klaten) berdasarkan Rencana Tata Ruang Wilayah (RTRW) Provinsi Jawa Tengah. Selain sebagai Kawasan Andalan Subosukowonosraten, berdasarkan Rencana Tata Ruang Nasional (RTRWN) Kota Surakarta juga berfungsi sebagai Pusat Kegiatan Nasional (PKN). Kota Surakarta dijadikan kawasan peruntukan industri skala wilayah untuk industri kreatif regional Provinsi Jawa Tengah. Pemerintah Kota Surakarta berupaya menyukseskan perencanaan regional dan nasional tersebut dengan mengembangkan industri kreatif, sektor jasa dan perdagangan Kota Surakarta serta mengembangkan 
kecakapan kota dan mengembangkan Sistem Inovasi Daerah melingkupi aspek infrastruktur inovasi secara komprehensif dan kolaboratif (Bapppeda, 2016).

Terdapat lebih dari 1250 pelaku industri kreatif dan bisnis rintisan di Surakarta dan jumlah tersebut meningkat 10\% dibanding tahun 2006. Data tersebut didapat dari jumlah peserta Bekraf Developer Day oleh Badan Ekonomi Kreatif di Surakarta 9 April 2017 dan Hasil Sementara Pendaftaran Usaha Sensus Ekonomi 2016 Tahap Awal Kota Surakarta oleh Badan Pusat Statistik Surakarta (BPS Kota Surakarta, 2016). Lebih dari 65\% pelaku industri kreatif dan bisnis rintisan tersebut tidak memiliki tempat kerja menetap. Selama ini lokasi bekerja mereka di rumah atau kafe padahal kondisi tersebut dapat menghambat produktivitas dan kreativitas para pelaku akibat gangguan yang terjadi dalam rumah atau kafe, serta terbatasnya fasilitas seperti presentasi, rapat, dan produksi.

Menurut KBBI daring, kata "Produktivitas" berarti kemampuan untuk menghasilkan sesuatu. Arti dari kata "kreativitas" yakni kemampuan untuk mencipta. Ruang yang menunjang produktivitas dan kreativitas dapat dimaknai sebagai ruang yang menunjang kemampuan untuk menghasilkan sesuatu dan menciptakan sesuatu.

Bangunan dan lingkungannya dapat memengaruhi aspek fisik, sosial, dan mental penggunanya. Terdapat empat faktor yang memengaruhi produktivitas (termasuk kreativitas berpikir), ditunjukkan pada Gambar 1, yakni aspek sosial, organisasi, lingkungan, dan personal (Clements-Croome, 2017). Lingkup arsitektural terdapat pada faktor lingkungan yakni perencanaan dan perancangan area bekerja.

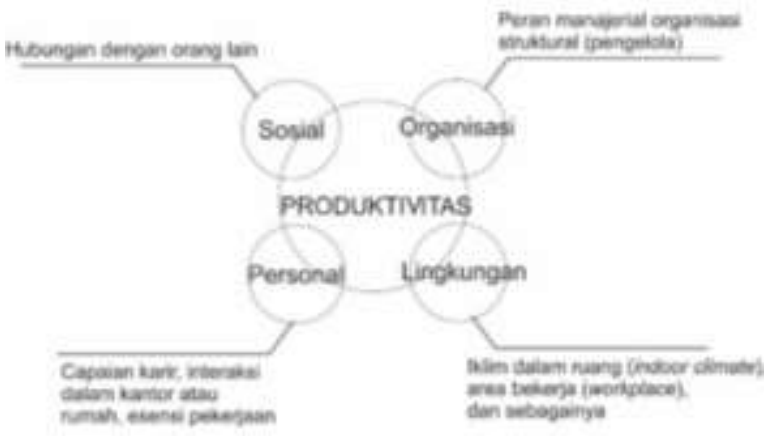

Gambar 1. Aspek Lingkungan Area Bekerja Berpengaruh pada Produktivitas
Sumber: Clements-Croome, 2017.

Faktor arsitektural yang menunjang produktivitas dan kreativitas pengguna yakni zonasi dan susunan ruang yang terpadu serta akses servis komunikasi dan informasi memadai (Schittich, 2011), simplifikasi dan fleksibilitas ruang yang memungkinkan adanya fleksibilitas alokasi area dan ruang kerja pengguna (Heath, 2012) serta ruang bebas memberikan peluang individu untuk lebih ekspresif (Ismail, 2016), pemilihan perabot yang ergonomis dan mendorong pergerakan fisik pengguna (Schittich, 2011), pemilihan warna sesuai karakter dan fungsi ruang serta adanya elemen natural (Clements-Croome, 2017), dan adanya sentuhan seni untuk membuat tempat bekerja lebih reseptif dan menstimulasi kreativitas di ruang kerja (Heath, 2012).

Isu dan potensi terkait Kota Surakarta, industri kreatif, bisnis rintisan, serta tinjauan adanya faktor arsitektural yang menunjang produktivitas dan kreativitas tersebut memunculkan gagasan perencanaan dan perancangan wadah berkegiatan berupa kantor sewa kolaboratif yang menunjang produktivitas dan kreativitas penggunanya.

Kantor sewa kolaboratif memberikan kesempatan bagi setiap orang yang ingin bekerja produktif dan kreatif tanpa harus memiliki kantor (Sari, 2018). Keuntungan lainnya yakni lingkungan tidak kaku, harga sewa lebih rendah, serta dapat dilakukan oleh individu dan bisa disewa dengan rentang waktu yang pendek yakni sehari. Kantor sewa kolaboratif memiliki perbedaan dengan kantor sewa umum karena di kantor sewa kolaboratif terdapat program jaringan antar anggota yang dikelola oleh pengelola.

Adanya sistem kepengelolaan dan kriteria ruang penunjang produktivitas dan kreativitas tersebut diharapkan dapat membuat kantor sewa kolaboratif menjadi wadah yang menguatkan jaringan dan hubungan antar pekerja, dapat mempertemukan dengan klien potensional yang baru, dapat mengatasi masalah pemeliharaan fasilitas kantor, dan mendukung produktivitas dan kreativitas bekerja bagi penggunanya. 


\section{METODE}

Konsep perencanaan dan konsep perancangan Kantor Sewa Industri Kreatif dan Bisnis Rintisan di Surakarta didapatkan melalui metode perencanaan dan metode perancangan.

Perencanaan dimulai dengan melakukan pengumpulan data dengan wawancara, observasi, preseden, serta studi literatur buku, perda, artikel, dan berita. Data yang didapat dianalisis secara deskriptif kualitatif terkait rencana kelembagaan pengelolaan, alternatif lokasi tapak, kegiatan, dan kebutuhan ruang. Data kemudian dianalisis dalam analisis perencanaan. Beberapa hal yang dilakukan dalam analisis perencanaan yakni analisis kelembagaan, analisis alternatif tapak, analisis kegiatan, dan analisis kebutuhan ruang.

Perancangan dimulai dengan melakukan analisis peruangan, ta pak, tampilan bangunan, sturktur, dan utilitas. Hasil analisis perancangan berupa kriteria-kriteria desain kemudian disintesis mejadi konsep perencanaan dan perancangan sebagai dasar transformasi desain untuk mendapatkan desain Kantor Sewa Kolaboratif Industri Kreatif dan Bisnis Rintisan di Surakarta.

\section{HASIL DAN PEMBAHASAN}

Analisis kelembagaan mendeskripsikan bahwa kelembagaan proyek arsitektur yang direncanakan merupakan proyek swasta yang memiliki kesesuaian dengan program pemerintah daerah Kota Surakarta dan menjelaskannya pada diagram struktur kepengelolaan bangunan.

Analisis alternatif tapak menghasilkan tapak perancangan yang sesuai dengan kriteria lokasi tapak kantor sewa kolaboratif. Peruntukan lahan kantor sewa kolaboratif ditandai dengan warna merah muda dan merah bata pada peta Kota Surakarta di lampiran nomor 1. Hasil tinjau lokasi sesuai peruntukan lahan menghasilkan tiga alternatif tapak perancangan kantor sewa kolaboratif. Tiga alternatif tapak tersebut dianalisis lebih lanjut terkait kriteria pemilihan tapak. Kriteria yakni dekat perkantoran umum, berada di kawasan strategis kota, dilalui kendaraan umum, dan tersedia jaringan utilitas yang memadai. Ketiga tapak telah memenuhi kriteria lokasi di kawasan strategis kota. Lokasi ketiga alternatif tapak ditunjukkan pada Gambar 2.

Analisis kriteria lokasi tapak lebih lanjut yakni alternatif tapak 1 berada di dekat sembilan perkantoran, dilalui lima kendaraan umum, dan tersedia enam jaringan utilitas komunikasi yang baik. Alternatif tapak 2 berada dekat dengan enam perkantoran, dilalui empat kendaraan umum, dan tersedia empat jaringan utilitas komunikasi. Alternatif tapak 3 berada dekat enam perkantoran, hanya dilalui satu kendaraan umum, dan tersedia empat jaringan utilitas komunikasi.

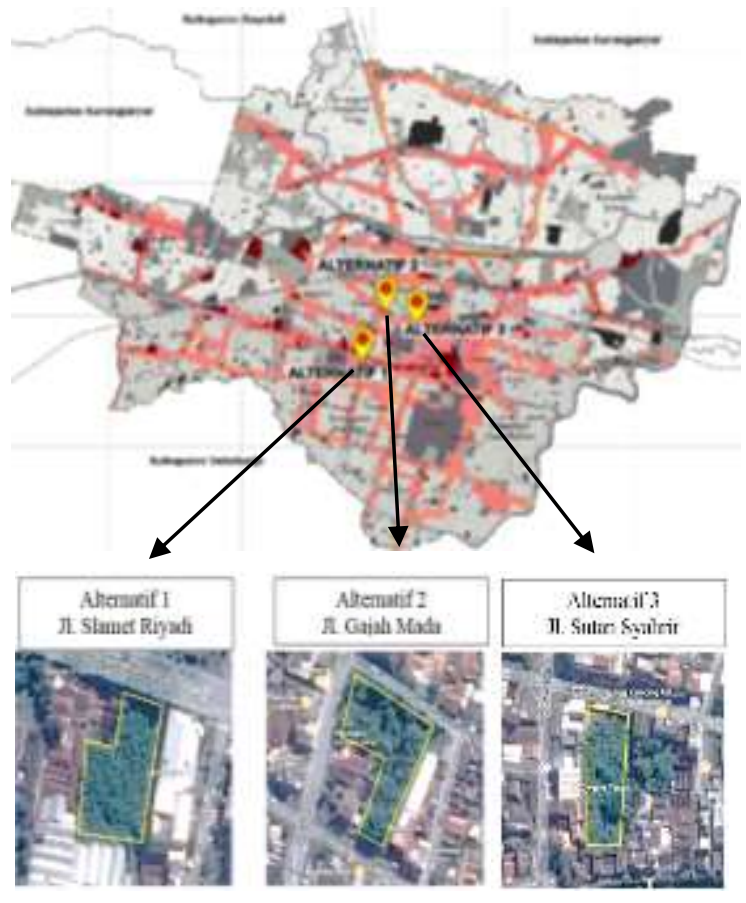

Gambar 2. Alternatif Tapak Berdasarkan Pertimbangan Lokasi Strategis Kota Sumber: Peta Dasar Google Maps, 2017.

Analisis alternatif tapak menghasilkan lokasi tapak terpilih yakni alternatif 1 Jl Slamet Riyadi No. 263, Kelurahan Sriwedari, Kecamatan Laweyan, Kota Surakarta, Jawa Tengah 57141 Indonesia. Luas tapak $\pm 2.755,5 \mathrm{~m}^{2}$.

Tapak memiliki batas lokasi perbelanjaan Sami Luwes di batas timur, bangunan kios dan bangunan House of Danar Hadi di batas barat, jalan Brigjen Slamet Riyadi di batas utara, dan bangunan sedang dalam proses renovasi di bagian selatan. Orientasi dari tapak yakni utara dengan batas atau menghadap Jalan Brigjen Slamet Riyadi. Ukuran tapak ditunjukkan pada Gambar 3. 
Analisis berikutnya adalah analisis kegiatan. Analisis kegiatan menghasilkan analisis lanjutan terkait pengguna, kegiatan, dan waktu kegiatan.

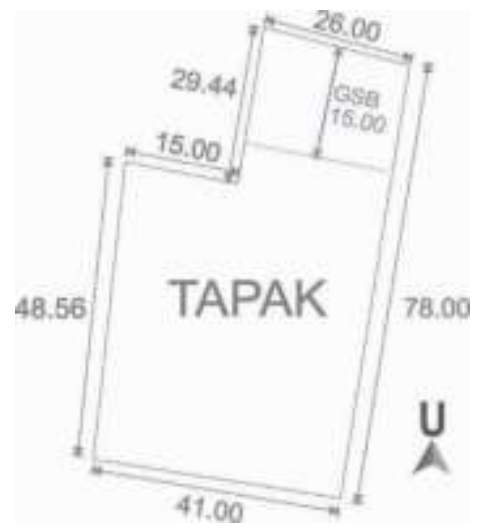

Gambar 3. Ukuran Tapak Perancangan Sumber: Peta Dasar Google Maps, 2017.

Pengguna bangunan terbagi dalam empat kelompok pengguna yakni pengelola, pengguna utama (pelaku industri kreatif dan bisnis rintisan), pengunjung, dan servis. Waktu berkegiatan pengguna utama yakni hari Senin hingga Sabtu pukul 08.00-00.00. Waktu berkegiatan pengunjung Senin sampai Sabtu pukul 09.00-21.00. Waktu berkegiatan pengelola Senin sampai Jum'at pukul 09.0017.00. Waktu berkegiatan pengelola jaga resepsionis yakni hari Senin sampai Sabtu pukul 08.00-00.00 dengan pembagian pergantian dua shift kerja. Kegiatan yang dilakukan pengguna utama, pengelola, dan pengunjung antara lain bekerja, berdiskusi, menerima tamu, melakukan produksi produk kreatif, presentasi, rapat, workshop, pameran.

Kebutuhan ruang pada bangunan yakni area pintu masuk (entrance atau drop off), ruang lobby, ruang loker, ruang bekerja atau coworking dengan jenis terbuka dan privat, runag studio kerja (dengan jenis: studio foto, studio video editing, studio recording, studio tari, studio seni), ruang rapat, ruang seminar, ruang baca, ruang santai (ruang brainstorming), pantry, kantin, retail, ruang percetakan, ruang pengelola (terdiri dari ruang CEO, ruang sekretaris, ruang manajer, ruang divisi dan staff pengelola), ruang kantor keamanan, ruang kantor teknisi, ruang informasi, ruang tamu pengelola, ruang arsip, gudang, janitor, ruang operator, ruang $M E$, ruang chiller, ruang genset, ruang pompa, ruang tangki air, mushola, toilet, tempat sampah, dan ruang parkir.

Hasil analisis kebutuhan ruang dianalisis kembali terkait luasan ruang, zona ruang, dan pola hubungan ruang. Total luas kebutuhan ruang yakni $\pm 10,624.855 \mathrm{~m}^{2}$ dengan rincian kelompok ruang pengguna utama $4635.05 \mathrm{~m}^{2}$, kelompok ruang penunjang $3062.9 \mathrm{~m}^{2}$, kelompok ruang pengelola $382.935 \mathrm{~m}^{2}$, dan kelompok ruang servis $298.97 \mathrm{~m}^{2}$.

Berdasarkan total luas kebutuhan ruang dan perhitungan KDB dihasilkan bahwa bangunan kantor sewa kolaboratif membutuhkan enam lantai bangunan dan dua lantai basement.

Kelompok ruang penunjang seperti lobby, ruang informasi, mushola, retail, ruang percetakan, dan ruang pameran merupakan zona ruang publik. Zona tersebut dapat diakses oleh pengguna utama, pengelola, dan pengunjung. Ruang tamu pengelola, ruang bekerja terbuka, dan ruang baca adalah zona ruang semi privat. Ruang bekerja privat, studio, ruang rapat, dan ruang pengelola adalah zona ruang privat yang hanya bisa diakses oleh pengguna tertentu. Zonasi secara keseluruhan bangunan ditunjukkan pada Gambar 4.

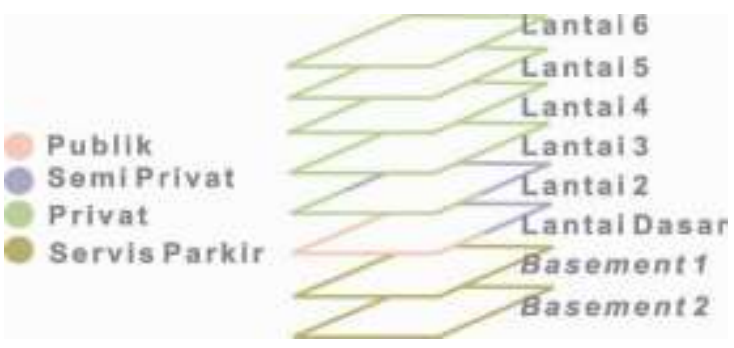

Gambar 4. Zonasi Vertikal dan Horizontal pada Bangunan

Sirkulasi pada bangunan dibagi dalam dua analisis, sirkulasi dalam bangunan dan sirkulasi pada tapak. Sirkulasi dalam bangunan berupa analisis pola hubungan dan aliran ruang. Terdapat dua aliran sirkulasi dalam bangunan yakni linear dan radial, dalam Gambar 5 ditunjukkan dengan latar warna krem untuk linear dan latar warna biru untuk radial. Pola hubungan ruang ada tiga jenis yakni melewati ruang, menembus ruang, dan menghilang dalam ruang. Pada Gambar 5 pola melewati ruang bertanda garis putus hijau, pola menembus ruang bertanda garis putus ungu, dan pola menghilang dalam ruang bertanda garis putus oranye. 


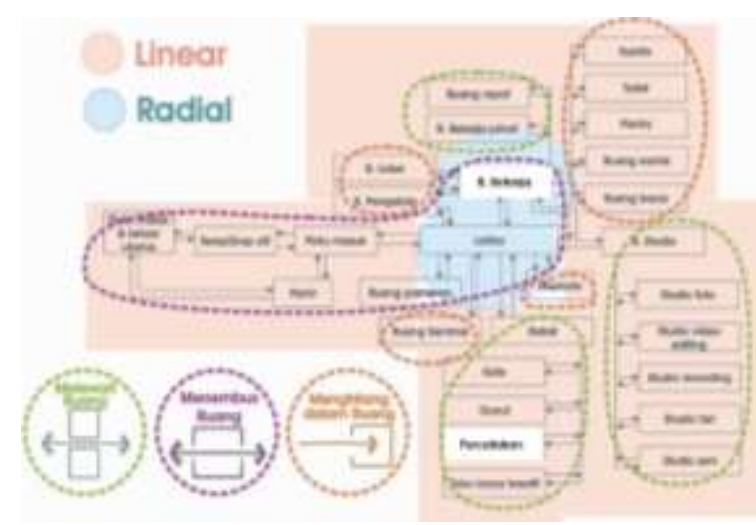

Gambar 5. Sirkulasi dalam Bangunan Kantor Sewa Kolaboratif Industri Kreatif dan Bisnis Rintisan di Surakarta

Sirkulasi pada tapak terdapat lima jalur yakni sirkulasi mobil atau motor drop off, sirkulasi mobil parkir, sirkulasi motor parkir, sirkulasi pejalan kaki, dan sirkulasi khusus (insidental). Sirkulasi pada tapak ditunjukkan pada Gambar 6. Sirkulasi drop off bertanda garis oranye. Titik penurunan dan penjemputan penumpang dapat dilakukan di titik A atau B.

Sirkulasi mobil parkir bertanda garis coklat. Lokasi parkir mobil berada di basement bangunan. Sirkulasi motor parkir bertanda garis hijau. Lokasi parkir motor juga pada basement bangunan. Pengguna dapat mengakses bangunan dari parkir basement melalui tangga atau elevator. Sirkulasi pejalan kaki bertanda garis ungu. Pejalan kaki dapat langsung mengakses ke dalam bangunan melalui titik A. Sirkulasi khusus yang bertanda garis biru adalah sirkulasi yang diakses pengguna ketika area titik B difungsikan sebagai ruang pameran luar ruang. Sirkulasi khusus bisa diakses oleh pengelola setiap hari.

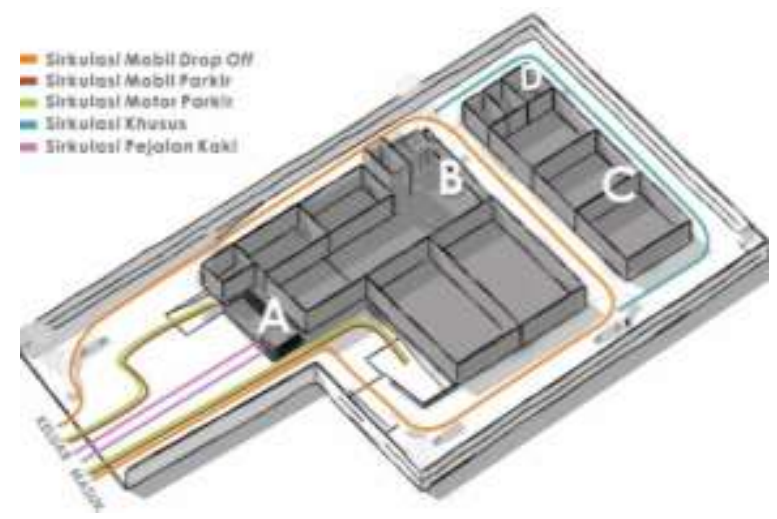

Gambar 6. Sirkulasi pada Tapak Kantor Sewa Kolaboratif Industri Kreatif dan Bisnis Rintisan di Surakarta
Lokasi tapak yang dekat dengan lampu merah membuat penempatan pintu masuk dan keluar utama menjauhi lokasi lampu merah untuk menghindari kemacetan ditunjukkan dalam Gambar 7.

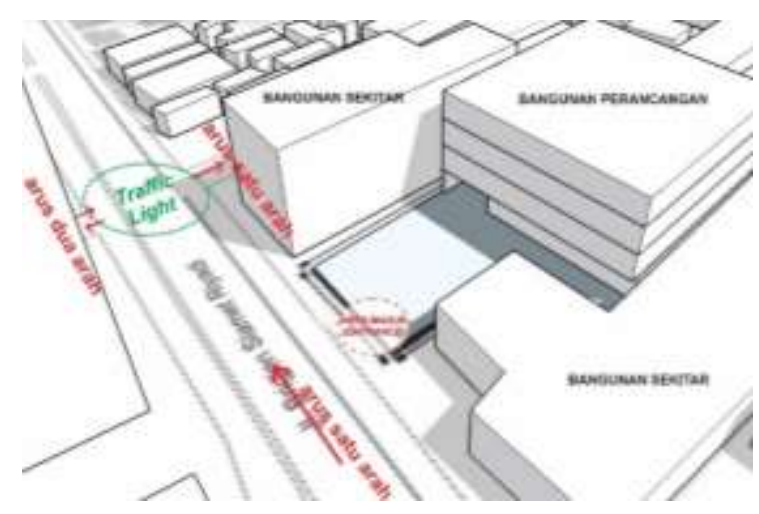

Gambar 7. Sirkulasi Pencapaian pada Tapak Kantor Sewa Kolaboratif Industri Kreatif dan Bisnis Rintisan di Surakarta

Tampilan interior bangunan dianalisis sesuai kriteria-kriteria ruang faktor arsitektural yang menunjang produktivitas dan kreativitas pengguna. Ruang dianalisis dengan kriteria karakter ruang, pemilihan warna ruang, pemilihan elemen kejutan, pemilihan tanaman, dan pemilihan perabot. Ruang-ruang yang dianalisis yakni ruang bekerja bersama, ruang bekerja privat, resepsionis, kafe, toko, ruang pengelola, dan ruang-ruang studio. Konsep kriteria tampilan ruang interior terdapat pada lampiran nomor 2. Desain ruang berdasarkan kriteria tampilan ruang ditunjukkan pada lampiran nomor 3.

Tampilan eksterior bangunan kantor sewa kolaboratif industri kreatif dan bisnis rintisan di Surakarta yakni bentuk bangunan berbentuk dasar bujur sangkar dengan penambahan dan pengurangan. Bentuk bujur sangkar membuat penataan dan pengembangan bentuk relatif mudah, kegiatan dengan berbagai orientasi dapat diwadahi, karakter bentuk yakni formal dan netral, fleksibilitas tinggi dengan penataan perabot yang cenderung mudah.

Bentuk bangunan tersebut berdiri bebas dalam tapaknya tapi meneruskan ruang interiornya untuk bersatu dengan ruang eksterior privatnya. Ruang interior yang menerus pada ruang eksterior privat adalah akses basement dan teras bangunan. Penambahan bentuk bujur sangkar sesuai dengan kebutuhan jumlah lantai bangunan dan substrasi untuk akses menuju 
basement dan penyatuan dengan ruang eksterior privat.

Bentuk dan tampilan bangunan muncul dari kebutuhan ruang dan bentuk ruang. Ilustrasi kemunculan bentuk bangunan terlihat pada Gambar 8. Per lantai bangunan ditata sehingga muncul bentuk bangunan kantor sewa kolaboratif di Surakarta.

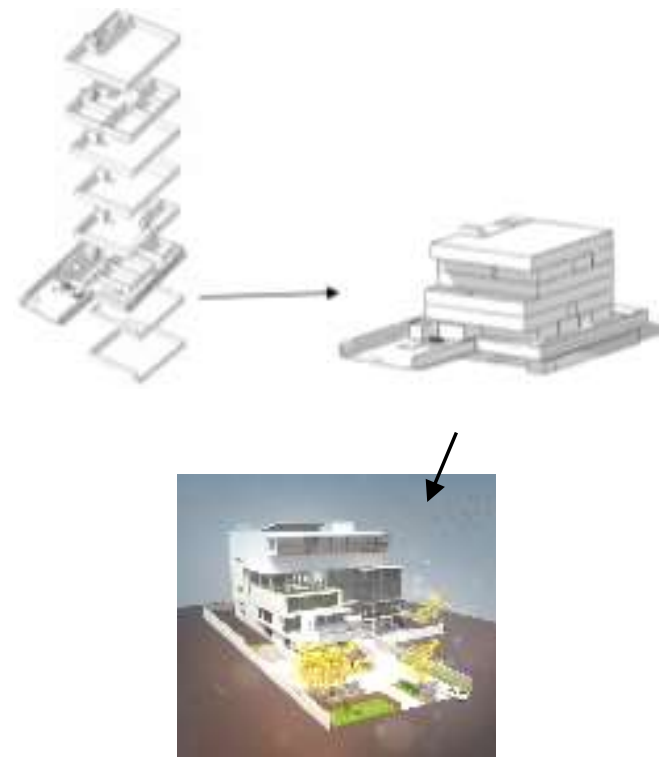

Gambar 8. Bentuk Bangunan Muncul dari Tatanan per Lantai

Tampilan bangunan berupa tampilan arsitektur modern dengan point of interest bangunan berada di bagian utara bangunan dengan menempatkan nama bangunan pada tampilan yang ditunjukkan oleh Gambar 10. Tampak depan bangunan didominasi penggunaan material kaca untuk memaksimalkan pencahayaan alami pada bangunan. Pada dinding kaca bagian barat dilapisi dengan lapisan film untuk mengurangi ketidaknyamanan pancaran sinar matahari sore yang menyengat dan menyilaukan.

Pandangan dari jalan ke tapak paling baik pada sisi utara tapak (Tanda A pada Gambar 9). Hal tersebut dimanfaatkan sebagai area penempatan nama bangunan dan area pintu masuk (entrance) utama bangunan.

Pandangan dari tapak paling baik yakni pandangan ke utara sehingga pada tampilan bangunan, sisi menghadap utara dimaksimalkan pandangannya dengan penggunaan material kaca. Warna tampilan eksterior monokrom untuk tetap menampilkan kesan formal kantor sewa kolaboratif.

Sistem struktur yang digunakan pada bangunan kantor sewa kolaboratif adalah menggunakan pondasi bor pile dan cakar ayam sebagai sub strukturnya, rigid frame dan core sebagai super strukturnya, dan kombinasi atap datar dan struktur atap baja ringan sebagai upper struktur bangunan.

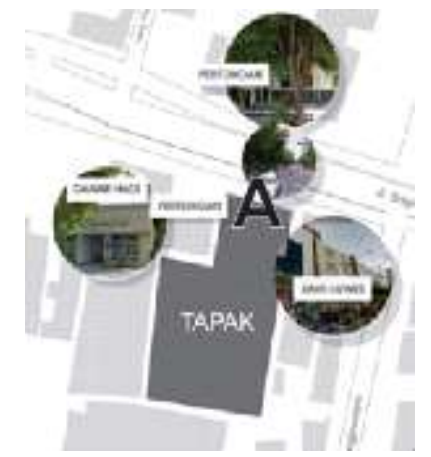

Gambar 9. Tampilan Depan Bangunan Kantor Sewa Kolaboratif Industri Kreatif dan Bisnis Rintisan di Surakarta

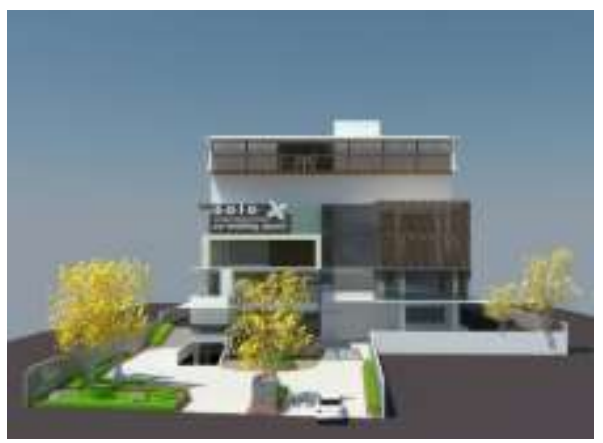

Gambar 10. Tampilan Depan Bangunan Kantor Sewa Kolaboratif Industri Kreatif dan Bisnis Rintisan di Surakarta

Bentuk sub struktur bangunan ditunjukkan oleh Gambar 11. Perbedaan ketinggian level tanah pada sisi tepi tapak dilakukan pengurugan. Semi basement 1 memiliki ketinggian di atas tanah setinggi 1.2 meter ditinggikan dari permukaan tanah agar terdapat aliran penghawaan alami dalam basement, sehingga basement tidak terlampau lembab terlebih pada basement 2. Batas antara basement dan batas tapak sejauh $1.5 \mathrm{~m}$ sesuai untuk sheet pile dan keamanan pondasi basement dan bangunan.

Sistem utilitas kantor sewa menggunakan kombinasi sumur pompa dan PDAM untuk mendapatkan ketersediaan air bersih; menggunakan pengolahan air kotor black water 
dan grey water dari bangunan untuk disalurkan ke tanah dan riol kota; meresapkan dan mengalirkan air hujan pada bangunan; melakukan distribusi listrik pada bangunan melalui shaft dan ducting dari PLN dan genset; menggunakan APAR, springler, dan hydrant untuk mencegah kebakaran bangunan, menggunakan sistem AC sentral dan split untuk penghawaan ruang; menggunakan jaringan WiFi dan LAN; serta menggunakan sistem keamanan CCTV, VMS, dan Access Control untuk bangunan.

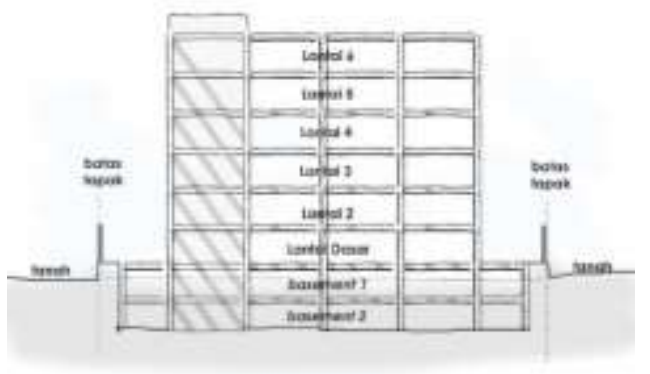

Gambar 11. Konsep Struktur Kantor Sewa Kolaboratif Industri Kreatif dan Bisnis Rintisan di Surakarta

\section{KESIMPULAN}

Kantor sewa kolaboratif industri kreatif dan bisnis rintisan di Surakarta adalah sebuah wadah bekerja dengan sistem sewa secara individu atau kelompok pelaku industri kreatif dan bisnis rintisan berlokasi di Kota Surakarta untuk meningkatkan produktivitas dan kreatifitas penggunanya. Lokasi perancangan di Jl Slamet Riyadi No. 263, Laweyan, Kota Surakarta, dengan luas tapak $\pm 2.755,5 \mathrm{~m}^{2}$.

Kantor sewa kolaboratif memiliki enam lantai bangunan dan dua lantai basement. Sirkulasi pada bangunan yakni linear dan radial dengan aliran sirkulasi melewati ruang, menembus ruang, dan menghilang dalam ruang. Sirkulasi pada tapak yakni sirkulasi pejalan kaki, motor, mobil, dan sirkulasi khusus pengelola.

Desain tampilan interior (lampiran nomor 3) dirancang sesuai konsep kriteria ruang yang menunjang produktivitas dan kreativitas penggunanya sesuai kriteria pada lampiran nomor 2. Desain tampilan eksterior kantor sewa kolaboratif yakni arsitektur modern untuk mendukung kebutuhan fungsi dan bentuk ruang bangunan. Penggunaan material industrial seperti kaca, beton, dan kayu sintetis mengurangi kebutuhan perawatan bangunan tanpa mengurangi nilai estetikanya. Aksen tampilan berupa motif batik pada kaca bagian depan bangunan memberikan identitas lokasi perancangan yakni Kota Surakarta.

Struktur yang digunakan yakni rigid frame dengan pondasi bor pile dan cakar ayam. Terdapat utilitas sanitasi, listrik, jaringan internet, keamanan, dan penghawaan bangunan.

\section{REFERENSI}

Bapppeda. (2016) Produk Hukum: Perda No 9 Tahun 2016 tentang Rencana Pembangunan Jangka Menengah Daerah Kota Surakarta Tahun 2016-2021.

BPS Kota Surakarta. (2016) Berita Resmi Statistik: Hasil Sementara Pendaftaran Usaha Sensus Ekonomi 2016 Tahap Awal di Kota Surakarta.

Clements-Croome, D. (2017). Creating Productive Workplace: Places to Work Creatively, Third Edition. London: Routledge.

Heath, Alex. (2012). Making Art Work in the Workplace. London: British Council for Offices.

Husada, T. R. (2015). Keuntungan Bekerja di Coworking Space. [Online] Tech in Asia.

Available from:

https://id.techinasia.com/keuntunganbekerja-di-co-working-space.[Diakses pada: 23 Agustus 2017].

Ismail, Fahlevi. (2016). Youthcenter di Kebumen sebagai Wadah Pengembangan Kreativitas Remaja dengan Pendekatan Psikologi Arsitektur. Jurnal Arsitektura vol. 14 No. 22016 hal 5.

Sari, Leny Indah. (2018). Ruang Co-Working untuk Kolaborasi Kreatif pada Pusat Komunitas Kreatif di Purwokerto. Jurnal Arsitektura vol. 16 No. 12018 hal 106.

Schittich, C. (2011). in Detail Work Environments (Spatial Concept, Usage Strategies, and Communications). Basel: Birkhauser. 


\section{LAMPIRAN}

\section{PERUNTUKAN KANTOR SEWA KOLABORATIF PADA PETA KOTA SURAKARTA}

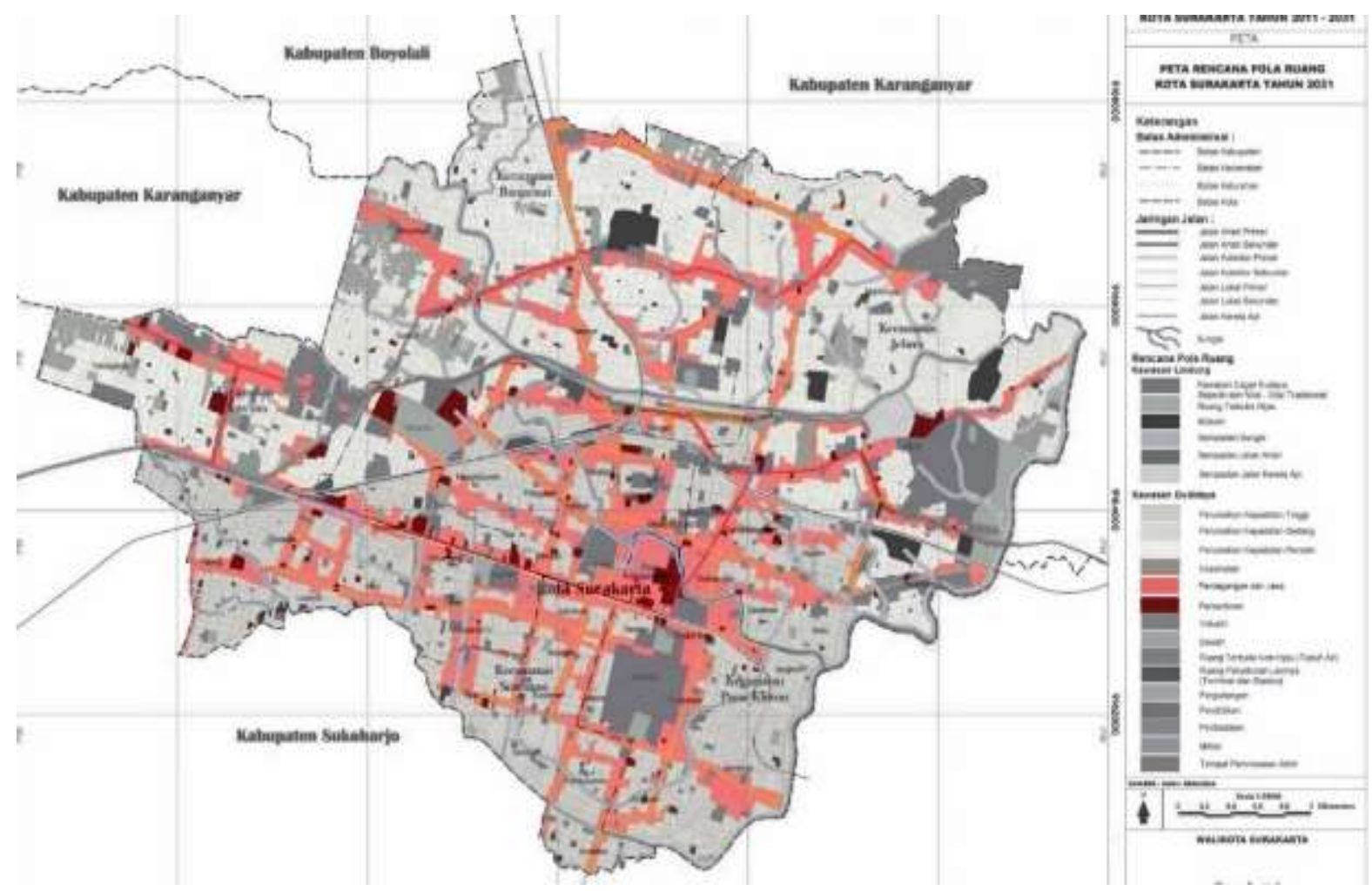

Peta RTRW Kota Surakarta dengan Fungsi Perkantoran dan Perdagangan Jasa ditunjukkan dengan Warna Merah Muda dan Merah Tua

Sumber: Peta Dasar Bapppeda Surakarta, 2012.

\section{KONSEP TAMPILAN INTERIOR RUANG}

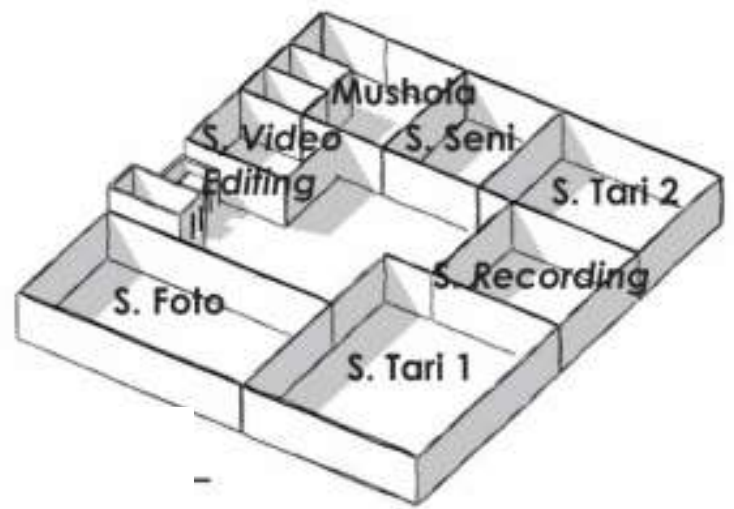

Karakter Ruang:

D Formol-semi format

o Serius.

Plilhan Warno

oranye o Merch

oputin o Hiliau

Pilihan Tanaman

o Hitam

- Dracaenc

o Philondendron

Pilihan Elemen Kejutan

o Teks dinding

o Lif perdamaion

- Lukisan dinding

Pilihan Perabot

Ruang studio membutuhkan

perabot berbeda-beda sesua

o Instalasi dinding

dengan jenis studionya. 


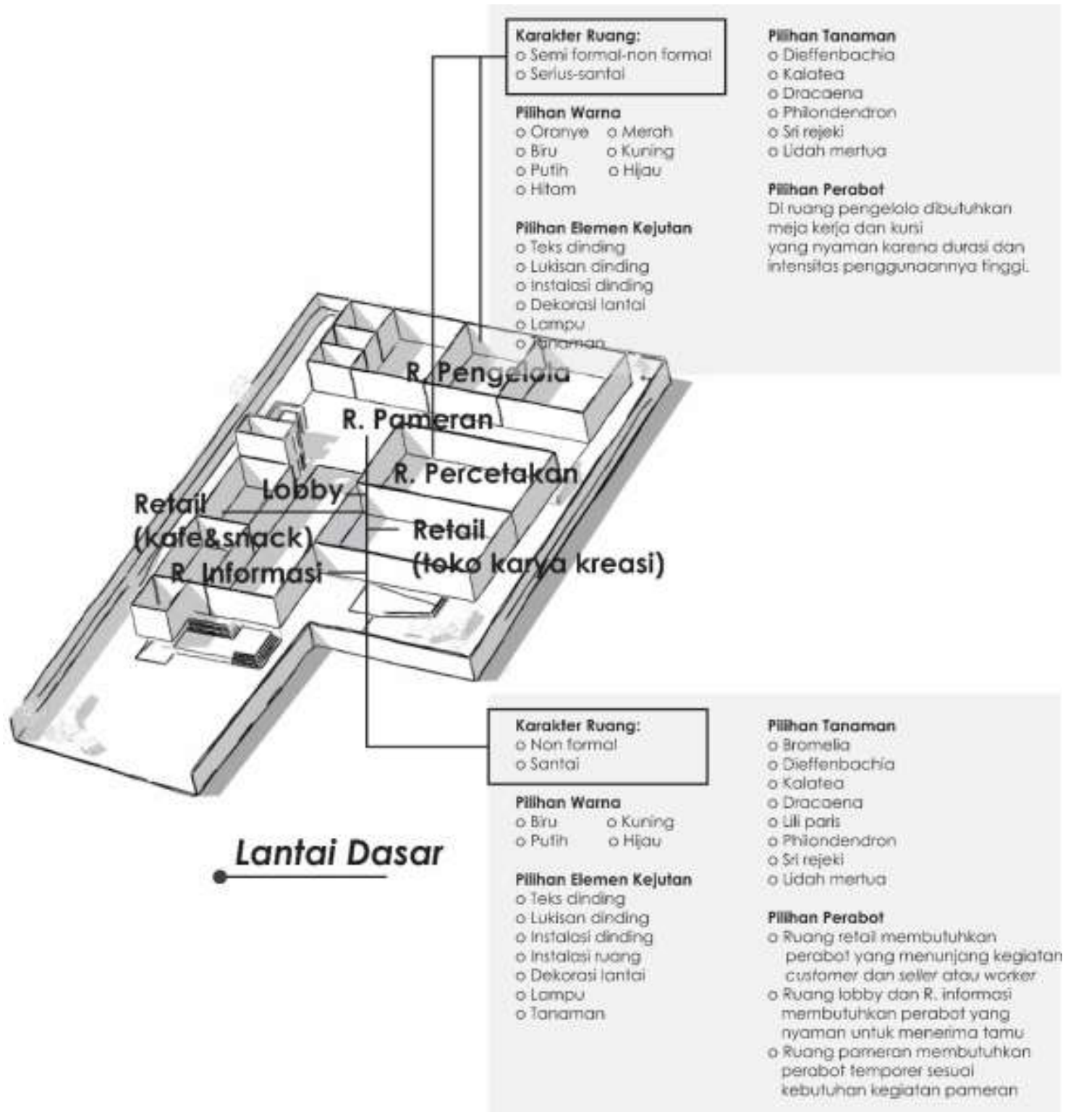




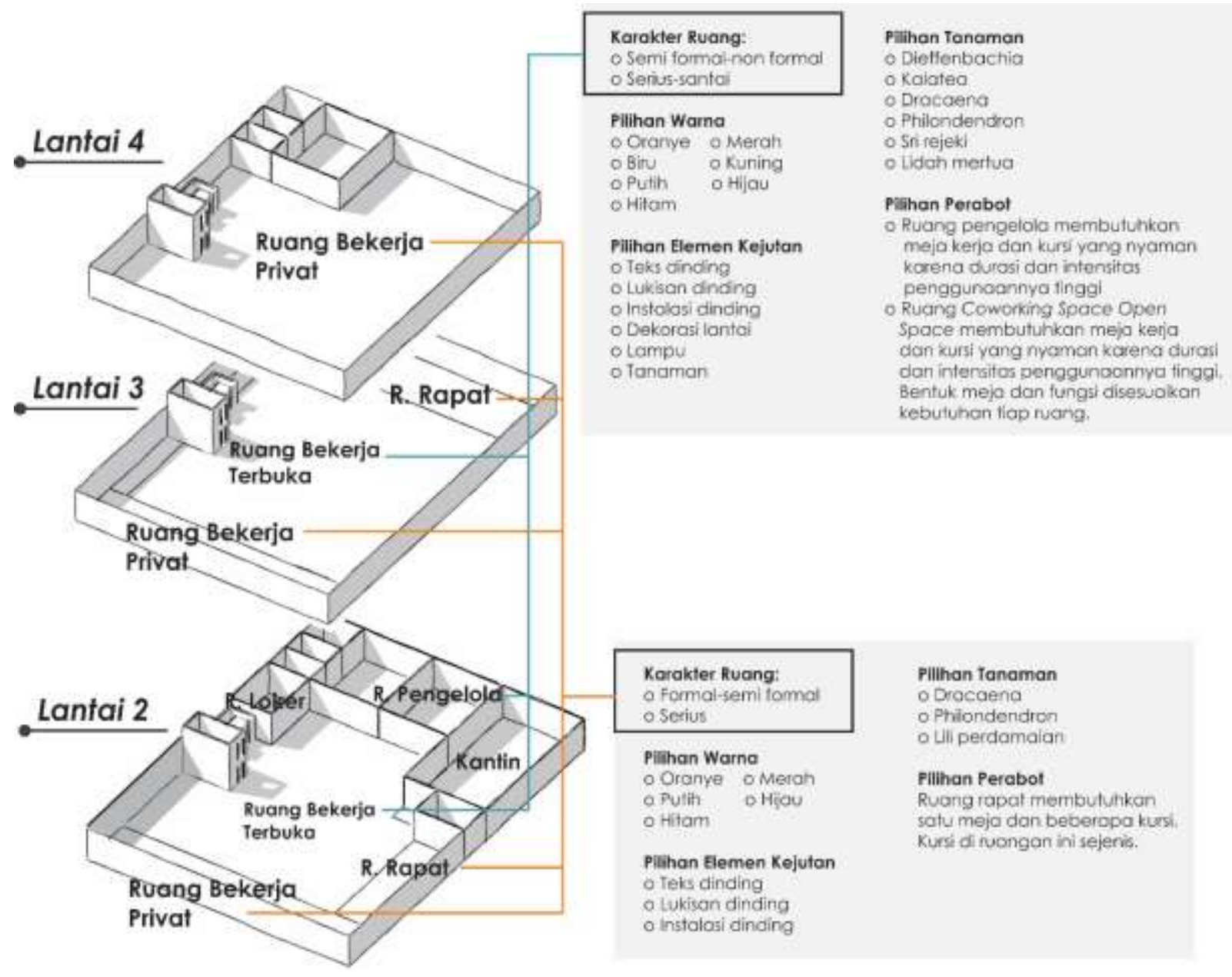

3. DESAIN TAMPILAN INTERIOR RUANG

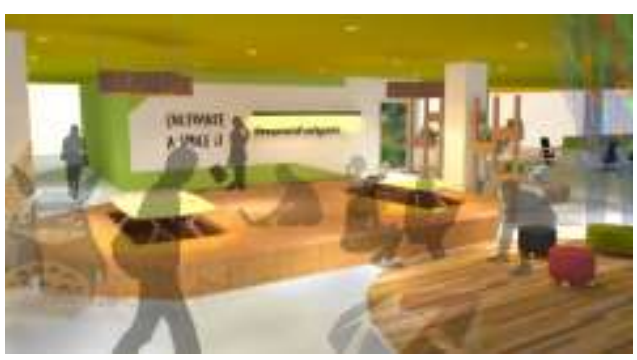

R. Bekerja Bersama (Area Lesehan)

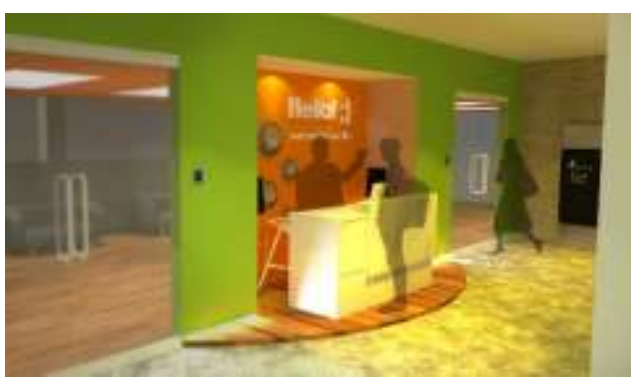

Resepsionis

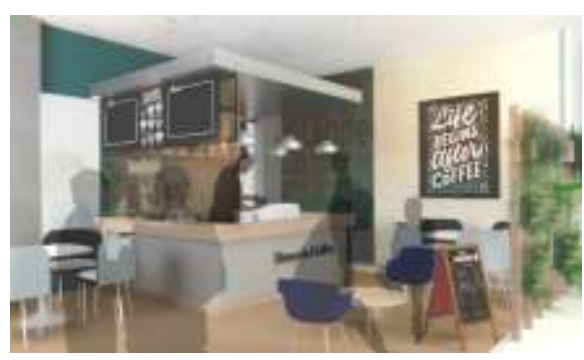

Kafe

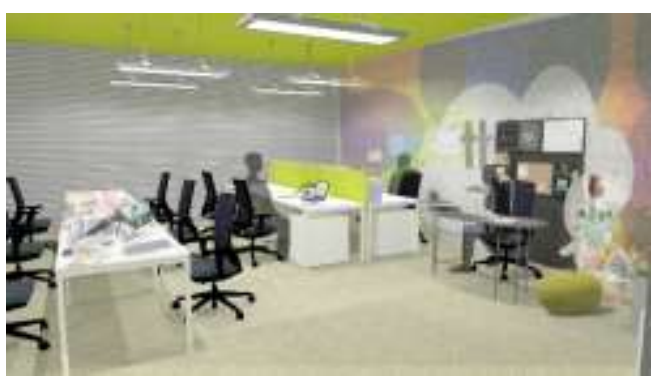

R. Bekerja Privat 